\title{
Arbor
}

\section{Diagnóstico y metodología de restauración en la escultura policromada}

\section{Marisa Gómez González, Teresa Gómez Espinosa}

Arbor CLXIX, 667-668 (Julio-Agosto 2001), 613-644 pp.

La policromía es la capa o capas, con o sin preparación, realizada con distintas técnicas pictóricas y decorativas, que recubre total o parcialmente esculturas o elementos arquitectónicos $u$ ornamentales, con el fin de proporcionar a estos objetos un acabado o decoración. Es consustancial a los mismos e indivisible de su concepción e imagen ${ }^{1}$.

La madera y la piedra han sido los materiales más comunes empleados por los artistas para realizar objetos tridimensionales que posteriormente se policromaban. La policromía, ilumina las formas de las figuras y busca un efecto de realismo, unas veces, de fantasía, otras, que varía también con la iconografía, la función de la obra, etc. Su estética propia es inseparable de la de la escultura y está sujeta a la evolución técnica y estilística de los diferentes períodos de la historia del arte. Además, hay otros materiales fundidos, tallados o modelados, de origen inorgánico — como los metales, la terracota, el yeso y el estuco-, u orgánico — como el marfil, el cuero y las fibras vegetales recubiertas de papel o papelón-, que pueden presentar una policromía completa o parcial ${ }^{2}$.

La escultura, por ser tridimensional y estar conformada mediante volúmenes, suscita problemas relativos a la materia constitutiva del material tallado, modelado o fundido, y al desigual desgaste de sus diferentes zonas. Si además está policromada, hay que atender al de- 
terioro y conservación de la policromía, el primero causado con frecuencia precisamente por las alteraciones internas estructurales.

Otro factor a tener en cuenta al tratar la escultura policromada es la riqueza del patrimonio imaginero hispano-americano. La conservación de la imaginería devocional debe necesariamente contemplar el desarrollo y vigencia del culto a las imágenes religiosas y su consiguiente trascendencia social. De hecho, son mayoría las esculturas de esta índole, frente a las que se conservan en los museos; por tanto, es necesario, cuando se trata de criterios, no olvidar este género de bienes cuyos valores trascienden los puramente artísticos. Hay ciertos parámetros que no podemos pasar por alto antes de intervenir, como son la escala dimensional de la obra y el alcance del tratamiento, que han de adecuarse siempre a su estado de conservación, así como su función religiosa o museística y las condiciones relacionadas con su ubicación posterior.

Aunque se ha abusado de las comparaciones entre la restauración y la medicina, no podemos evitar sustraernos a la tentación de mencionar una frase pronunciada por una de las personas más relevantes en el ámbito de la escultura policromada, Agnes Ballestrem, en la inauguración del curso internacional impartido sobre esta especialidad: "Así como el conocimiento del cuerpo humano hace que el médico reconozca o interprete con acierto un mal funcionamiento del mismo, el conocimiento de las técnicas artesanales y artísticas, y de los materiales empleados por los artistas de épocas y regiones diversas, permiten al restaurador reconocer e interpretar correctamente las alteraciones de las obras» (Brasil, 1989). Compartimos plenamente el significado profundo de estas palabras, que han constituido en todo momento el planteamiento que trataremos de desarrollar en este artículo. Las consideraciones que vamos a exponer están fundamentadas en documentos de reconocido prestigio internacional, como las Cartas del Restauro ${ }^{3}$ (la última fechada en Roma en 1987) y en nuestra propia Ley del Patrimonio de 1985.

Antes de acometer cualquier intervención, es imprescindible realizar una investigación previa. Este estudio se hará de acuerdo a las diferentes circunstancias de cada obra, como su relevancia desde el punto de vista histórico artístico, o su función, es decir, si se trata de una imagen de culto o de colección museística o particular. Además, se tendrá en cuenta el interés que plantea su estado de conservación o su futuro tratamiento, para poder diseñar la metodología de trabajo más eficaz desde la perspectiva de la investigación en estos campos.

Es necesario recopilar toda la información posible sobre los trabajos anteriores a la talla propiamente dicha - aserrado, desbastado, ahue- 
cado etc.- y la realización de modelos a pequeña escala, modelados o vaciados. Hay que localizar las huellas de los instrumentos y las marcas de fábrica o de colocación de las piezas. También interesa observar la terminación de la superficie y su textura, en especial en las esculturas de piedras nobles, como el alabastro, policromadas de forma parcial. Por el contrario, cuando se trata de la madera, hay que determinar si han sido enlenzadas las uniones de las piezas, se han eliminado los nudos y se han reparado los defectos de la talla. Los ojos postizos, reliquias o documentos, entre otros, se introducen antes de proceder a aplicar la policromía. A veces, también la talla se enriquece con joyas, orlas y otros ornamentos, acoplando piedras semipreciosas y vidrios, cuerdas, semillas e incluso conchas, y pegando o ensamblando piezas de madera que forman pequeños relieves.

La policromía incluye numerosas técnicas. Al encolado del soporte sigue el aparejado o enyesado ${ }^{4}$, que consiste en aplicar manos sucesivas de yeso gris, cuando se trata de maderas de coníferas, aunque esta capa puede ser inexistente en las maderas compactas de frondosas, o en zonas especiales, como las encarnaciones. El yeso blanco inerte, fino y untuoso, proporciona una superficie lisa adecuada para el correcto acabado del aparejo, seguida de una impregnación aislante de aglutinante puro que hace menos absorbentes las capas de policromía. La piedra, las yeserías, los estucos y las terracotas no suelen llevar este tipo de preparación; su policromía puede ir directamente sobre la superficie labrada o modelada o sobre una fina y compacta imprimación local, hecha al óleo. Las encarnaciones de las figuras pueden ser mates, pulimentadas, o mixtas; el pulimento se realiza frotando la pintura antes de secar con una vejiguilla o cubriendo la superficie con un barniz brillante. La mayoría de las vestiduras y decoraciones arquitectónicas de los retablos e imágenes de culto hispanoamericanas están decoradas con aplicaciones de hojas metálicas de oro, plata, estaño o bronce, imitando al oro. Los dorados y plateados bruñidos al agua van siempre sobre una fina capa de $b o l^{5}$-en general de color rojo y ocasionalmente amarillo-, mientras que el espesor, el aspecto y el composición del mixtión, pigmentado o no, de un dorado mate pueden variar de forma considerable. Algunas veces, la naturaleza y la procedencia de los pigmentos empleados nos ayudan a caracterizar y datar las policromías ocultas de una talla repolicromada. Numerosas técnicas decoran los dorados y plateados, como el picado de lustre, el esgrafiado y el estofado a punta de pincel, brocados aplicados en relieve, pastillas, barbotinas y pequeños motivos decorativos de papel prensado. 
Por último, es indispensable recopilar información sobre las prescripciones de calidad de los materiales que van a utilizarse en el proceso de restauración, su procedencia y las instrucciones necesarias para una correcta manipulación.

Es muy frecuente, cuando se trata este género de bienes, encontrarse con una serie de problemas comunes, derivados, en unos casos, de su función devocional, y en otros, de factores extrínsecos a la escultura. Así se encuentran las sucesivas remodelaciones de que han sido objeto las imágenes a causa de los cambios de gusto y de normas doctrinales; las consecuencias del culto propio de cada una de ellas, que suelen tener una mayor incidencia en su deterioro cuando, además, son procesionales; la inclusión de un amplio repertorio de postizos; las intervenciones antiguas, y algunas recientes, muchas de ellas irreversibles. Son raras las imágenes que han quedado a salvo de sucesivas manipulaciones. A lo dicho anteriormente hay que sumar otros resultados de la acción antrópica, comunes al resto de los géneros artísticos, tales como los provocados por las guerras, las exclaustraciones, las agresiones, los actos de vandalismo...

\section{Equipo de trabajo}

Todos los estudios e investigaciones previos al tratamiento han de ser realizados por un equipo interdisciplinar de profesionales compuesto por historiadores, científicos, restauradores y, si procede, arquitectos, cuando las esculturas se encuentren integradas en bienes inmuebles, como es el caso de los retablos. Es esencial que todos ellos tengan una formación global, a la vez que cuenten con una amplia experiencia y estén sensibilizados para trabajar en este campo. De esta forma estarán capacitados para contemplar la obra con el máximo respeto, mantener un diálogo abierto y valorar, tanto el aspecto material y la técnica de ejecución, como el histórico, artístico y funcional indispensables para garantizar una intervención ejemplar.

Esta comisión de especialistas debe asumir, no sólo los trabajos derivados de la intervención propiamente dicha, sino el seguimiento posterior que corrobore la eficacia del tratamiento. También ha de diseñar las condiciones de mantenimiento - exposición, almacenamiento, traslados...- y controlar las incidencias que se produzcan desde el momento final de la intervención, para prevenir futuras alteraciones $\mathrm{y}$ resolverlas con mayor rapidez. 
Diagnóstico y metodología de restauración.......

\section{El restaurador}

Se encarga de realizar un informe previo detallado de la naturaleza, estructura y construcción de la obra y su estado de conservación, así como de proponer el tratamiento de conservación que considere más adecuado. El examen visual del especialista contempla el estudio del soporte de la obra, incluidos la arquitectura en el caso de los retablos, la peana en las esculturas de bulto redondo, y el marco en los relieves. También refleja el aspecto del aparejo y la policromía propiamente dicha, la presencia de postizos, capa de protección y el estado de conservación de cada una de las partes mencionadas. El proyecto de intervención debe abarcar las fases de trabajo y la metodología empleada en cada una de éstas, así como los productos utilizados.

\section{El historiador}

Debe hacerse cargo de reunir una documentación lo más exhaustiva posible, por lo cual es necesario el trabajo en archivos y la recopilación de noticias, ya sea bibliográficas, gráficas u orales, que puedan encontrarse, abarcando en su estudio, no sólo los aspectos históricos y estilísticos, sino también los técnicos, así como la historia material de la obra, averiguando su procedencia, los traslados de que ha sido objeto, las anteriores intervenciones a las que haya podido ser sometida $\mathrm{y}$ los eventuales agentes externos que hayan podido influir en su deterioro. Gran parte de esta búsqueda consiste en revisar documentos de archivos, tratados de la época, libros de fábrica de las iglesias y contratos de obra, y en contrastar esta información con la suministrada por los testigos presenciales de las últimas intervenciones o catástrofes relacionadas con el estado actual del objeto. También hará constar todos los datos de interés que surjan durante el tratamiento de la obra.

\section{El personal científico}

Interviene en el examen previo de la obra desde distintas perspectivas. El estudio de conservación preventiva supone establecer las condiciones más adecuadas que deberán mantener los recintos de exposición de la obra, restauración o almacenamiento, así como los requisitos exigidos para su traslado. 
El personal del laboratorio implicado en el estudio diseña la secuencia analítica a seguir para determinar la naturaleza del soporte y las piezas que lo forman, la composición y estructura de los elementos que constituyen las capas de policromía. El diagnóstico del estado de conservación detecta o confirma las posibles alteraciones y sus causas. $\mathrm{Su}$ objetivo es completar los datos históricos, conocer la técnica de ejecución adoptada por el artista y el comportamiento de la obra a través del tiempo hasta formar la imagen plástica que hoy se ofrece a nuestra contemplación.

El tratamiento de restauración puede seguirse, desde el laboratorio, por medio de ensayos previos, asesorando sobre los parámetros a tener en cuenta en las distintas etapas y las ventajas e inconvenientes del uso de los productos propuestos por el restaurador. Asímismo, es interesante comprobar su eficacia, una vez finalizada la restauración. $\mathrm{Si}$ se realizan además controles periódicos posteriores de las obras restauradas, empleando parámetros objetivos de valoración, se evidenciará antes cuádo será necesaria una nueva intervención.

Como vemos, el personal científico realiza tareas muy diversas y utiliza muchas veces técnicas instrumentales complejas. Para que la interpretación de los análisis sea idónea, recomiende las condiciones ambientales más adecuadas o realice un correcto seguimiento, habrá de conocer profundamente las técnicas y materiales de la escultura policromada y la secuencia y los productos utilizados en los tratamientos. Esto exige, no sólo una especialización creciente, sino una proximidad continua en la labor de restauración. Científicos italianos que trabajan en instituciones de reconocido prestigio, como el «Restauro» de Roma y el «Opifricio delle pietre dure», de Florencia, han comprendido muy bien la necesidad de que los científicos no trabajen de forma aislada, sino "a pie de andamio", dando ejemplo de entrega y participación en el trabajo, que son difíciles de igualar.

\section{Estudio previo y seguimiento de la intervención}

Los trabajos interdisciplinares deben efectuarse de forma paralela $\mathrm{y}$, tras exponer y discutir los resultados obtenidos, se tratará de establecer un diagnóstico y formular unas conclusiones adecuadas que establezcan cuál ha de ser el tratamiento de conservación y restauración más idóneo con mayores garantías y respeto hacia la obra. En caso de que surjan problemas concretos que susciten polémica a la hora de decidir el tratamiento, el equipo de trabajo deberá llegar a un 
acuerdo común, sólidamente justificado, y nunca se actuará siguiendo una decisión unilateral. La responsabilidad de la intervención no es únicamente del restaurador, sino de todo el equipo y, si se considera necesario, se puede crear una comisión asesora de seguimiento de los trabajos, en la que también se pueden integrar, junto a los especialistas, personas responsables designados por los propietarios.

No vamos a entrar a detallar los fundamentos de las técnicas instrumentales que contribuyen a la conservación preventiva, el estudio previo y el seguimiento de una intervención, ya que han sido expuestos en el número monográfico anterior de la revista, dedicado a la conservación del patrimonio artístico. Sólo mencionaremos las aplicaciones más frecuentes de las técnicas habituales que sustentan el diagnóstico de los daños que justifican el tratamiento de una escultura policromada.

\section{Documentación fotográfica}

El trabajo de los fotógrafos ha de reflejar el estado inicial de la obra, anterior a la restauración y las distintas fases del proceso y el resultado final, una vez aplicado dicho tratamiento. Efectúan tomas generales, de las distintas vistas del objeto tridimensional y de los detalles representativos desde el punto de vista estilístico y de los aspectos relacionados con el deterioro, así como de las modificaciones que se han producido durante la intervención. Esta documentación es esencial, no sólo para demostrar el criterio seguido en el trabajo, sino como ayuda de cualquier investigación de historia del arte que vaya a realizarse sobre la pieza.

\section{Análisis físico}

La fotogrametría es necesaria en los retablos y grandes conjuntos, para identificar y registrar los posibles fallos estructurales: desniveles, desprendimientos, desplomes, etc. Entre otras cosas, sirve de referencia para el estudio iconográfico realizado por el historiador, la elaboración de los mapas de daños por parte del restaurador y la localización estricta de las muestras tomadas por químicos, biólogos y geólogos. La planimetría, además del alzado principal, debe incluir las plantas detalladas de los distintos cuerpos o partes que componen el conjunto y una sección tomada desde el eje principal. 


\section{Marisa Gómez González, Teresa Gómez Espinosa}

620

1. Radiografía de una escultura de madera policromada, donde se ve el contraste entre las zonas ahuecadas y las formadas por varias piezas reforzadas por clavos

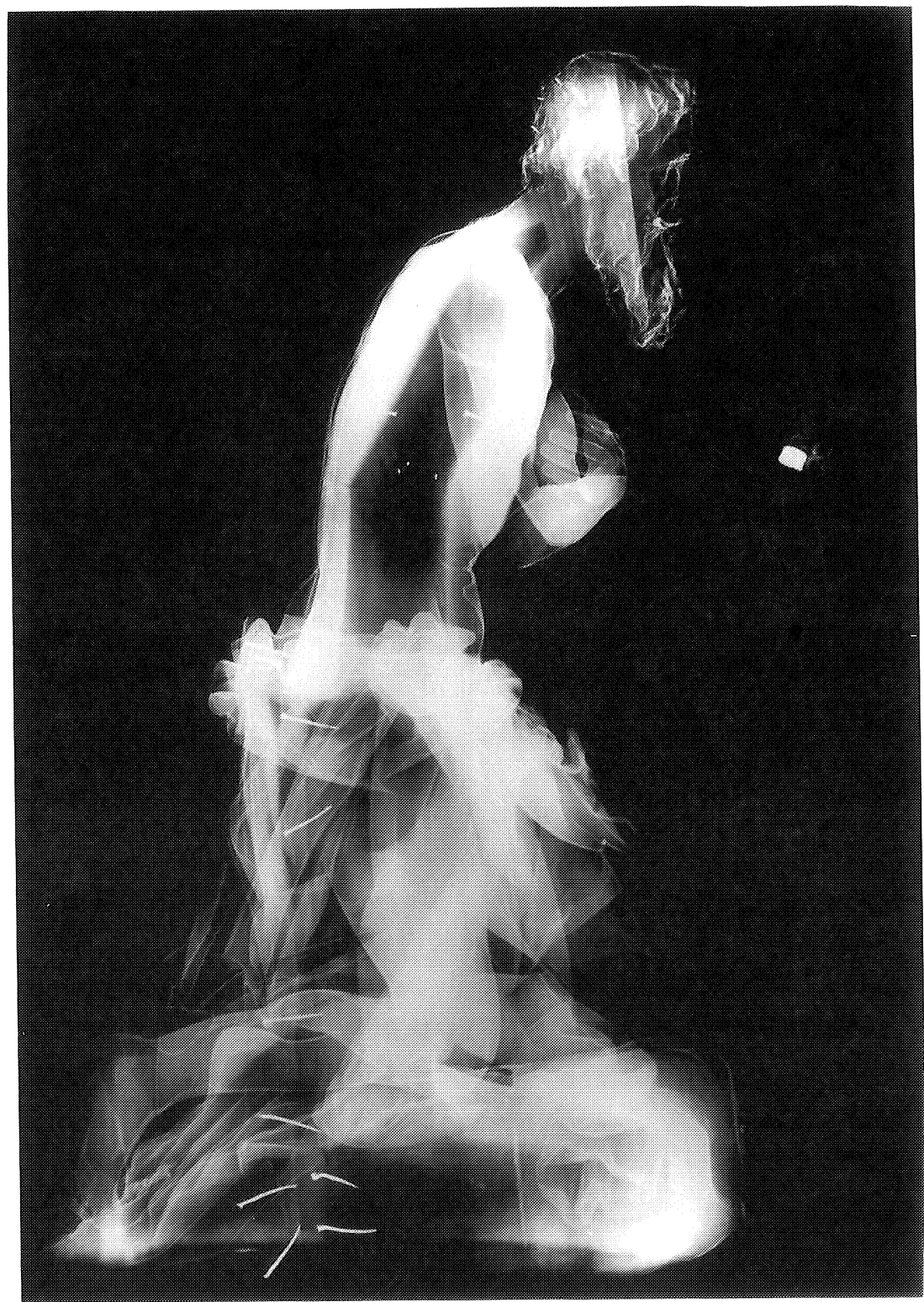


Diagnóstico y metodología de restauración.......

La reflectografía de infrarrojos es una técnica utilizada más frecuentemente en la pintura y de escasa aplicación en la escultura. En cambio, la fotografía de fluorescencia con lámpara ultravioleta es de mayor interés para desvelar la presencia de repintes, barnices envejecidos o pérdidas, localizar las juntas de unión entre las piezas de una obra en madera policromada o servir de ayuda en el proceso de limpieza.

La radiografía de una escultura policromada es un documento esencial para conocer la composición, y el estado del soporte, ya que éste se halla revestido por la policromía. Cuando el soporte es de madera, se emplea para determinar el número y la disposición de las piezas, la forma de ensamble y la presencia de clavos, tornillos $u$ otros anclajes (figura 1). Con esta técnica podemos detectar si se trata de piezas macizas o han sido ahuecadas y descubrir posibles objetos introducidos en su interior. En las esculturas en piedra el interés de la radiografía es menor, ya que el soporte suele constar de una sola pieza, aunque sirve también para localizar poros, fisuras $\mathrm{u}$ otros defectos, uniones y vástagos de refuerzo procedentes de antiguas reparaciones.

$\mathrm{El}$ endoscopio se usa en retablos para acceder a la parte posterior oculta e introducirse en el interior de esculturas de madera con tapa o que sirven de relicarios, sin necesidad de desmontar una parte de la obra o retirar la cubierta. Las imágenes obtenidas se graban en vídeo, lo cual permite registrar esta documentación y compararla con los resultados facilitados por las radiografías.

\section{Análisis químico}

La metodología de trabajo y la secuencia de técnicas de análisis empleadas van a depender siempre de varios factores, como los componentes de la obra, si es necesaria o no la toma de muestra, el tamaño de ésta o el tipo de dato que se quiere obtener.

Cuando es necesario extraer muestras de policromía, se escogen áreas protegidas, lugares discretos o que presenten correspondencia - límite entre dos zonas de color-, y los puntos en que se localizan las calas realizadas mecánicamente por el restaurador. La metodología es similar a la de las prospecciones arqueológicas. En primer lugar, se estudia al microscopio óptico la morfología de las muestras y se determinan la sucesión de capas, el color y el espesor de cada una de ellas, las características ópticas de los pigmentos y la presencia de barnices o repintes etc. Se describen el color, textura, aspecto, de- 


\section{Marisa Gómez González, Teresa Gómez Espinosa}

coración, espesor y sucesión de las capas y se hace un esquema representativo: figurativo o en escalera.

El análisis propiamente dicho se efectúa por medio de técnicas instrumentales específicas de materiales orgánicos e inorgánicos. Hay técnicas analíticas complejas que pueden realizarse aprovechando la preparación microscópica, mientras que otras exigen aislar previamente un fragmento minúsculo de cada capa.

La espectrometría de infrarrojos por transformada de Fourier (FTIR), acoplada o no a un microscopio, es una técnica indispensable para determinar la naturaleza de los compuestos existentes en un fragmento desconocido, procedente de una capa o parte de ella, restos de un adhesivo, un barniz, etc. A partir de los resultados obtenidos, a menudo seleccionamos un segundo método analítico más específico de identificación de un producto. Permite identificar determinadas sales inorgánicas, así como los grupos funcionales de los materiales orgánicos.

La espectroscopía de rayos $\mathrm{X}$ es el método más habitual de análisis elemental. La fluorescencia por dispersión de energías de rayos $\mathrm{X}$ puede realizarse directamente sobre la superficie pintada, sin toma de muestra, o bien emplearse para analizar muestras introducidas en la cámara de un microscopio electrónico de barrido acoplando un detector de rayos $\mathrm{X}$ (SEM-EDX). Ambas técnicas sirven para caracterizar la mayoría de los pigmentos inorgánicos existentes en la policromía. Hoy en día se están desarrollando también espectrómetros provistos de una fuente externa de tipo láser o basados en la inducción de partículas (PIXE).

Los aglutinantes de las capas pictóricas se localizan mediante ensayos con colorantes selectivos y su composición se determina usando técnicas cromatográficas, como la cromatografía en capa fina, la cromatografía de gases, que puede asociarse a un espectrómetro de masas y la cromatografía liquida de alta presión.

Para descifrar mejor la composición de las distintas policromías, muchas veces conviene confeccionar tablas comparativas que indican la localización y la extensión de cada capa, o policromía, resultantes de los estudios efectuados en los diversos puntos a partir de las calas, estratigrafías, análisis de aglutinantes y de pigmentos. En la interpretación de los datos hay que seguir un criterio sistemático y riguroso, partiendo de la posible existencia de técnicas y texturas diferentes en la misma obra. De este modo, se puede establecer si la policromía original era parcial o total, la localización de las distintas ornamentaciones y técnicas utilizadas en la obra y su estado de conservación. 
Diagnóstico y metodología de restauración.......

\section{Metodología y criterios de intervención}

En este punto, nos referiremos, en líneas generales, a los aspectos básicos más comunes en los procesos de restauración de escultura policromada. El tratamiento no puede dirigirse sólo a restaurar la policromía que decora las formas escultóricas, sino que tiene que resolver primero las alteraciones del soporte que compone el conjunto. Cuando se trata de un retablo, es necesario tener en cuenta su relación con los elementos arquitectónicos, que afectan a su estado de conservación o su estabilidad, elementos constructivos, anclajes y refuerzos.

\section{Tratamiento del soporte}

La primera etapa en la restauración de un objeto o conjunto de madera policromada consiste en una inspección detenida que indique si es necesario comenzar por la desinfección o desinsectación del soporte, si es que éste es objeto de ataque biológico. Se procurará aislar la pieza, usar un gas idóneo y evitar, en lo posible, la utilización masiva de productos líquidos que tenga que embeber la madera.

A veces resulta necesario consolidar el soporte de madera, piedra, etc., cuando ha perdido su consistencia, e incluso reponer piezas, aunque esto último sólo debe justificarse por necesidades estructurales, empleando materiales de comportamiento semejante frente a los factores ambientales y resistencia mecánica ligeramente inferior a los originales.

\section{Fijación, adhesión y consolidación de la policromía}

El refuerzo de la adhesión del aparejo y la película pictórica debe hacerse siempre que éstos lo requieren, por encontrarse desprendidos del soporte, o cuando se detecte una falta de adherencia entre sí. El adhesivo fortalece la unión entre dos capas o la de una capa con el correspondiente soporte. Denominamos fijativo al compuesto que une una escama superficial a una capa subyacente. Cuando no se trata de partes escamadas, sino de capas disgregadas, debe procederse a la consolidación interna de éstas. La conveniencia de los productos a utilizar se estudiará de acuerdo a las características de la policromía, teniendo en cuenta que nunca deben alterar su aspecto primitivo. 


\section{Marisa Gómez González, Teresa Gómez Espinosa}

\section{Limpieza y eliminación de repintes}

En primer lugar, hay que determinar si nos encontramos ante un repinte, una reintegración o una repolicromía y decidir qué es lo que se puede y debe eliminar y lo que debe conservarse. En todo caso, la limpieza tiene que ser homogénea, nunca caprichosa, pues de ser así, pueden crearse falsos históricos y acabados confusos. La intervención debe limitarse al mínimo imprescindible de acuerdo a lo establecido en la metodología de trabajo decidida por la comisión de especialistas.

Ya se haga a través de medios mecánicos o utilizando productos de los que se conozca su fundamento de actuación, nunca deben alterarse la estructura ni el cromatismo de la obra. Hay que utilizar materiales de composición conocida y, aun así, realizar ensayos previos con disolventes y otros productos, localizadas en zonas discretas, ayudándose con una lupa binocular.

En ningún caso la limpieza será profunda, pues siempre ha de conservarse el aspecto superficial, o «pátina» ocasionada con el paso del tiempo, así como respetar los restos eventuales de barnices antiguos, siempre y cuando no se encuentren tan alterados que modifiquen el tono original y dificulten la contemplación de la policromía.

En el supuesto, bastante frecuente, de que la obra haya sido repolicromada una o más veces, debe evitarse la eliminación sistemática de repolicromías. La eliminación de repolicromías injustificada o decidida unilateralmente causaría una pérdida irreparable de información, salvo que sea correcta y exhaustivamente documentada. La no eliminación de una repolicromía no significa renunciar al conocimiento de la subyacente, pues puede reconstruirse a partir de la metodología de un preciso estudio de las distintas policromías, trabajo delicado e indudablemente laborioso, para el que hace falta material especializado. Hay que tener en cuenta que la eliminación de una policromía exige una considerable inversión de horas de trabajo.

La decisión de eliminar una repolicromía sólo puede justificarse tras la exposición de sólidos argumentos. Nos consta que, en demasiadas ocasiones, se han perdido irremediablemente estos testimonios de los cambios de gusto y estilo a lo largo de la historia. La eliminación de una repolicromía debe ser aceptada, en todo caso, por una comisión interdisciplinar de especialistas, justificándose su viabilidad desde todos los puntos de vista: material, histórico, estético y funcional.

Una vez decidida la eliminación, antes de intervenir se debe realizar una completa descripción y documentación de la policromía que incluya 
Diagnóstico y metodología de restauración........

toda la información posible sobre la misma. Localizados con discreción, deben dejarse testigos significativos de la policromía eliminada

\section{Reintegración}

Previamente se determinará el criterio a seguir en las reintegraciones y la metodología de trabajo, siendo prioritario el máximo respeto al original. Cuando se trata de imágenes devocionales, aunque algunos se escuden en este hecho para realizar reintegraciones ocultas de policromía, no es necesario, normalmente, llegar a tal extremo. En muchas ocasiones, tras efectuar la limpieza, las lagunas quedan perfectamente integradas en el efecto cromático de conjunto, haciendo innecesarias las reintegraciones. Hay que tener en cuenta que, otras veces, las lagunas se deben a las manipulaciones propias del culto, lo que supone un desgaste o erosión que debemos entender que forma parte de su historia, pues son manifestaciones propias de la religiosidad popular inherentes a nuestra cultura y tradición y, por tanto, es necesario respetar estas huellas.

Por lo que se refiere a la policromía, las reintegraciones deben justificarse por la recomposición de la correcta lectura de la misma. Según las circunstancias, se podrá elegir entre diversas soluciones: punteado, rayado, tintas planas,.... Si las faltas, una vez realizado el proceso de limpieza y consolidación, dejan la madera del soporte vista, de manera que el tono de ésta no distorsiona con el conjunto cromático, no será necesario efectuar reintegraciones.

Siempre que sea posible, se recurrirá a cualquier documento, gráfico o escrito, que aporte datos fidedignos de su aspecto primitivo.

En cuanto al soporte, en ocasiones es preciso efectuar consolidaciones o reintegraciones por mor de la estabilidad de la obra. Dependiendo de la amplitud de la laguna a reintegrar y de las características de la misma, se utilizará madera, previamente tratada, piedra, etc., o bien materiales sintéticos. En las imágenes procesionales las intervenciones estructurales son, en ocasiones, bastante radicales y aparatosas, especialmente cuando hay que afrontar anteriores restauraciones poco afortunadas realizadas con materiales y métodos inadecuados y agresivos.

Toda reintegración debe ceñirse exclusivamente a los límites de la laguna, se llevará a cabo con materiales inocuos y reversibles, claramente discernibles del original y distinguibles al ojo desnudo a una distancia prudente, dejando especialmente reconocible la reintegración en las zonas adyacentes a lo original. 


\section{Capa de protección}

Deberá aplicarse solamente cuando se considere necesario para que proteja la obra durante su exposición, evitando la alteración del acabado primitivo y respetando en cualquier caso el acabado propio de cada estilo artístico. La aplicación de un barniz espeso a brocha sobre un objeto tridimensional puede producir acumulaciones en las partes interiores del relieve, que luego son muy difíciles de eliminar, mientras que si la mezcla está diluida en exceso se produce un deslizamiento que provoca acumulaciones en las partes inferiores. Para utilizar un depósito uniforme de la película de protección se recomienda efectuar procedimientos de nebulización.

Hay que tener en cuenta que las esculturas de materiales nobles, como alabastro y piedra caliza, albergadas en el interior de un edificio no han sido protegidas originalmente y, cuando se aplican sobre ellas acabados brillantes, se falsea de modo innecesario su aspecto anterior. Las corlas, los esgrafiados y los estofados que decoran muchas policromías son capas muy delgadas y delicadas y la aplicación de un barniz espeso, o de un producto que endurezca de forma irreversible por la acción de los agentes ambientales, pueden dificultar o imposibilitar la limpieza en un tratamiento ulterior.

\section{Informe final}

Todo el proceso de conservación y restauración constará por escrito en un informe técnico exhaustivo, realizado por el restaurador, que irá ilustrado con fotografías y gráficos representativos de las distintas fases y que se completa con el resto de los informes efectuados por el personal del laboratorio y por los historiadores.

Cualquier intervención sobre una obra de interés cultural constituye un momento privilegiado para realizar un estudio cuyos objetivos son el conocimiento de la historia material de la obra y su evolución en el tiempo. En caso de existir policromías superpuestas, se trata de reconstruir gráficamente cada una de ellas, lo que se denomina correspondencia de policromías. La exploración se realiza con ayuda de un microscopio estereoscópico y el estudio que se complementa con la apertura de pequeñas ventanas o calas, y la información obtenida puede documentarse a través de una cámara de vídeo adaptada al sistema de aumentos y se completa con los análisis del laboratorio. Se trata de recopilar la mayor documentación posible para el conocimiento de 
Diagnóstico y metodología de restauración.......

la evolución de las técnicas polícromas y los motivos decorativos a través de la historia del arte. Para ello es necesario determinar: el número de policromías sucesivas, la estratigrafía de cada una de ellas, su localización y extensión, y sus características más relevantes - como color, textura, porosidad, etc.-, el tipo de decoraciones, los motivos representados, el estado de conservación y la datación absoluta o relativa de las mismas. La reconstrucción gráfica de las policromías puede realizarse manualmente o con ayuda de un tratamiento de imagen asistida por ordenador.

El informe de conservación preventiva debe hacer constar las condiciones a que estaba sometida la obra antes del tratamiento, evaluando sus consecuencias sobre su estado material, así como los correspondientes requisitos seguidos durante la intervención. También deberá incluir las recomendaciones necesarias para su mantenimiento posterior: condiciones termohigrométricas, ventilación, iluminación, vibraciones, manipulación,...

\section{Exposición y mantenimiento}

La obra será reintegrada a su ubicación original, siempre que reúna las condiciones adecuadas; no obstante, se evitará hacerlo si la restauración ha sido motivada por el mal estado ambiental del lugar en que se encontraba, salvo que, previa o paralelamente, otra intervención haya subsanado esos problemas y se pueda garantizar la conservación de la obra.

De ahí en adelante deberán controlarse sistemáticamente las variaciones ambientales del local y del lugar concreto donde se ha instalado la obra, evitando en lo posible los factores de riesgo. Para ello será preciso elaborar un programa de mantenimiento regular, lo que ayuda, por otro lado, a avanzar en el mejor conocimiento de la evolución de los tratamientos aplicados y los materiales y productos utilizados. El programa de mantenimiento deberá recoger de forma precisa las medidas a adoptar en cada caso concreto.

Es evidente que muchas de las imágenes devocionales, en particular las procesionales, están sometidas a frecuentes situaciones de riesgo y es necesario mentalizar, tanto al público, como a los propietarios de la obra, acerca de la necesidad de combinar el culto con unas mayores medidas de seguridad durante su transporte y exposición.

Merecen mención especial los retablos situados en inmuebles dedicados al culto, ya que su ubicación en el edificio es un factor primordial 
de la conservación de la obra. Unas veces, constituye en sí una garantía de mantenimiento, cuando los muros son gruesos y protegen el recinto de las variaciones termohigrométricas exteriores; otras, los problemas del inmueble son la causa principal del deterioro del retablo.

Los retablos y esculturas albergados en museos presentan una situación diferente; ordinariamente, la limpieza periódica y las medidas de seguridad están mejor controladas y las condiciones ambientales más reguladas. Sin embargo, factores que contribuyen al deterioro de estas obras son el mal estado de los locales que albergan los fondos de muchas colecciones y los traslados a que dan lugar los préstamos y exposiciones. El informe de conservación preventiva debe contemplar las medidas a seguir en el almacenamiento, transporte y embalaje de estas obras, sobre todo las esculturas policromadas de madera y otros soportes orgánicos, en cuyo deterioro las variaciones higrométricas juegan un papel fundamental.

La divulgación de los trabajos de investigación y restauración es imprescindible para suscitar interés y apoyo de la sociedad en la conservación del Patrimonio y para la formación de los profesionales de la conservación y restauración.

\section{Ejemplos prácticos}

La mejor forma de ilustrar cómo se lleva a cabo el diagnóstico y el modo en que éste influye en la metodología y criterios seguidos en la restauración es exponer algunos trabajos realizados por el personal del Instituto del Patrimonio Histórico Español. No pretendemos que éstos resulten representativos del amplio abanico de experiencias que puedan producirse en este campo, sino perfilar ciertos ejemplos, que esperamos merezcan la atención del lector.

El Cristo de Siresa es una talla románica de madera del siglo XIII, de tamaño natural, que se hallaba oculta en el muro posterior adosado al altar de la iglesia de esta localidad de Huesca. En un principio, se supuso que no había sido intervenida y conservaba su policromía original, pero más tarde se descubrió en un lateral del paño de pureza una laguna próxima al muslo derecho que ofrecía la visión de una policromía anterior más acorde con el espíritu románico.

El aparejo está compuesto por yeso y cola animal. Después de examinar las muestras al microscopio óptico, se ha estudiado por espectrometría de infrarrojos, identificando las bandas correspondien- 
tes al sulfato, el agua de hidratación y la proteína. Se han realizado también ensayos de coloración con negro amido y fuchsina y se han hecho los análisis de proteínas por HPLC y la determinación elemental por SEM-EDX.

En la mayoría de las muestras aparecían dos policromías superpuestas, aunque no en todas. Los pigmentos de la capa superior no eran muy lejanos en el tiempo de los de la original. Las encarnaciones estaban ejecutadas «al huevo», siendo la inferior más clara y matizada que la superior. La policromía interior del paño de pureza presentaba dos coloraciones diferentes: el anverso era azul, compuesto por lapislázuli sobre una base gris clara de albayalde y negro carbón, mientras que el reverso era de color rosado, de albayalde y laca roja, con matices lineales que representaban de forma ilusionista el relieve de los pliegues. Todo él estaba cubierto por una repolicromía blanca de albayalde puro, con una doble cenefa verde y rojiza (figuras 2 y 3 ).

El cabello y la barba eran pardos, elaborados con negro carbón y bermellón, en forma de gruesos granos. La cubría una repolicromía parda realizada con tierras.

Toda la superficie de la escultura se hallaba oculta por una costra de arcillas del enterramiento que contenía diversas sales - silicatos y fosfatos-, lo que hacía necesaria su eliminación. La policromía de la escultura tendía a levantarse a causa del espesor de la costra que la cubría y su higroscopicidad y por ello fue necesario aislarla durante todo el proceso en un recinto en el que estuvieran controladas las condiciones ambientales. La dificultad de separar la costra de la repolicromía nos llevó a decidir finalmente eliminar también ésta, aunque en un principio se había pensado conservar la repolicromía y documentar las decoraciones de la original ${ }^{6}$.

A pesar de la superioridad de la policromía original, hecha sin duda por un buen artista del siglo XIII, era lógico pensar que fue cubierta a causa principalmente de su deterioro. El azul del perizonio original estaba decorado en los bordes con una franja roja de puntos hecha con bermellón y con flores intercaladas de perfil romboidal con un centro y cuatro puntas, realizadas aplicando una lámina de estaño, aunque de la mayoría sólo quedan las incisiones hechas para ubicar los motivos. Estas aplicaciones metálicas constituyen un antecedente de los «brocados aplicados» en relieve de los siglos XV y XVI. Lamentablemente, no ha sido posible conocer las incrustaciones que bordeaban dicho perizonio y gran parte de las decoraciones de estaño se han deteriorado o perdido y las láminas de metal que restan se hallan agrisadas. 


\section{Marisa Gómez González, Teresa Gómez Espinosa}

2. Detalle de la cala del perizonio del Cristo de Siresa. Repolicromía gótica de color blanco con una doble cenefa roja y verde. Original azul oscuro con decoraciones de estaño, doble cenefa de puntos rojos y línea oscura. La secuencia de los orificios desvela las incrustaciones perdidas.

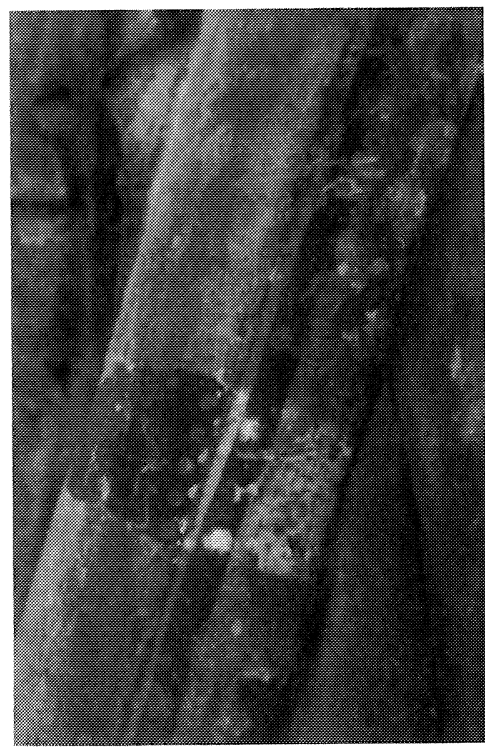

3. Microfotografía del perizonio de Cristo. Base inferior gris, capa de lapislázuli sobre la que se adhiere la decoración de estaño, cubierta por la repolicromía de color blanco.

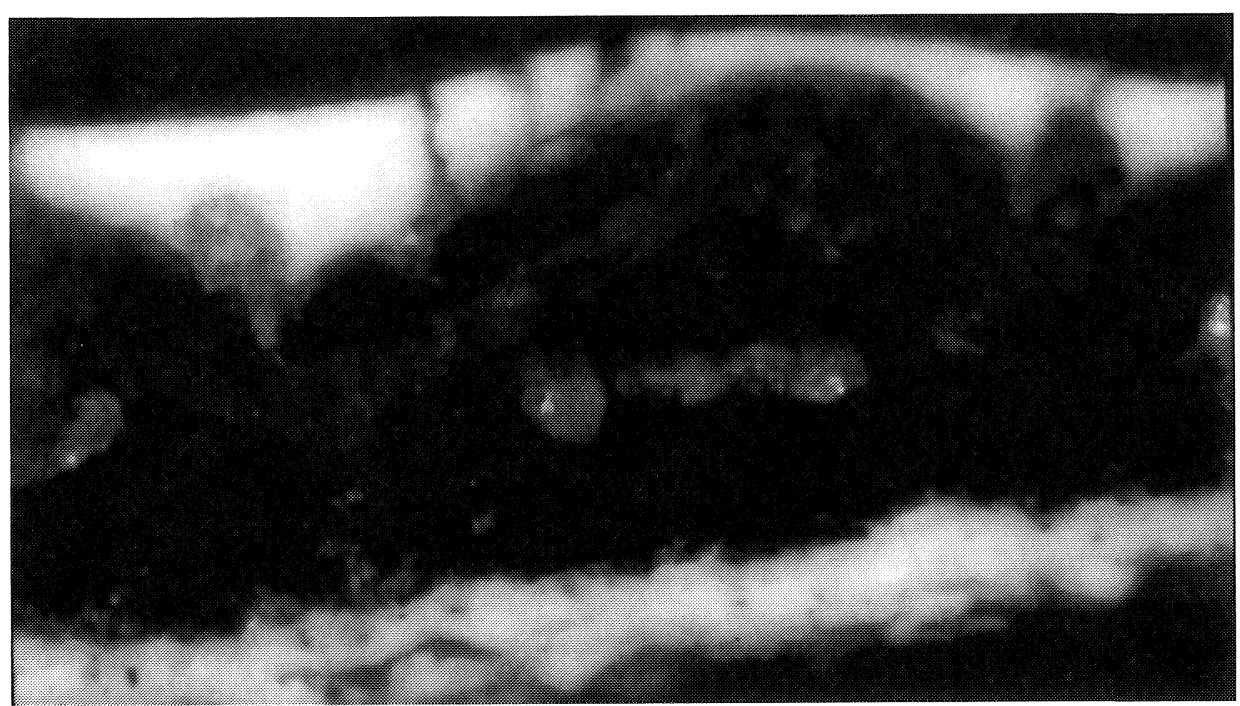


La Virgen con Niño de la Iglesia de Santa María del Campo es una escultura del siglo XV, de mediano formato, en caliza policromada, realizada en bulto redondo para ser vista de frente, por estar esbozada en la parte posterior. La obra está tallada en un solo bloque y la amplitud de la indumentaria le confiere cierta pesadez, aunque sin perder la gracia del conjunto. El Niño se halla sentado sobre el brazo izquierdo de la Virgen y a ésta le falta la mano derecha que sujetaba el manto (figura 4).

La policromía está aplicada directamente sobre la piedra en algunos colores opacos y planos, mientras que lleva hasta cinco capas en los matices, decoraciones y relieves. Las encarnaciones están compuestas por blanco de plomo y bermellón al óleo y han sido repolicromadas. La policromía exterior está más matizada y realizada «a pulimento».

El dorado de los cabellos de Nuestra Señora y del Niño, así como el manto de la Virgen, son mates y se asientan sobre una base 0 mixtión pigmentado de color verdoso anaranjado compuesto por un pigmento verde semejante a la malaquita, aunque de escasa calidad, minio y amarillo ocre (figura 5).

La túnica azul de María está hecha con azurita aplicada sobre una base oscura, compuesta esencialmente de negro carbón, ambas al temple, y constituyen una excepción frente al resto de la escultura.

El color rojo del reverso del manto de la Virgen está formado por una sola capa de bermellón puro al óleo. Sobre el fondo verde de la peana se aprecian pinceladas también verdes, de un pigmento de naturaleza mineral más basto que la malaquita y pardas, hechas con tierras ricas en óxido de hierro. El calzado está decorado con capas sucesivas negras — negro carbón-, rojas — bermellón- y anaranjadas -minio-.

Se observan brocados aplicados parciales en la túnica azul, en el reverso rojo del manto de la Virgen, y en el vestido rosado del Niño. Aunque estas decoraciones metálicas están muy dañadas, en todas ellas aparece una lámina de estaño formando un relieve rellenado con una mezcla de cera de abeja y una pequeña cantidad de resina. No se han detectado panes de oro o plata en tales motivos decorativos, aunque estos pueden haberse perdido, ya que se trata de zonas de la policromía muy deterioradas. Sobre dicha hoja de estaño o inmediatamente próximos a ella sólo hay restos de capas rojizas compuestas por laca roja o bermellón.

La restauración no reconstruyó la mano faltante de la imagen, ni eliminó la repolicromía de las encarnaciones ${ }^{7}$. Se limitó a fijar cuidadosamente la película de color, prestando especial atención a la túnica 
Marisa Gómez González, Teresa Gómez Espinosa

4. Imagen de la Virgen con niño de Santa María del Campo en bulto redondo, donde observamos la falta de la mano derecha de Nuestra Señora

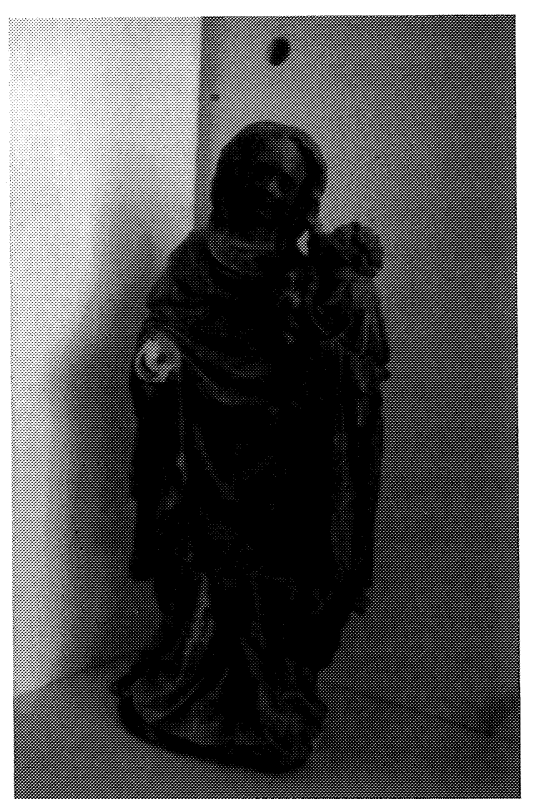

5. Microfotografía del manto dorado de la Virgen. Espeso mixtión, formado por una matriz ocre con gruesos granos verdes de la malaquita y anaranjados de minio. Superficie irregular del dorado mate con restos de "pan de oro"

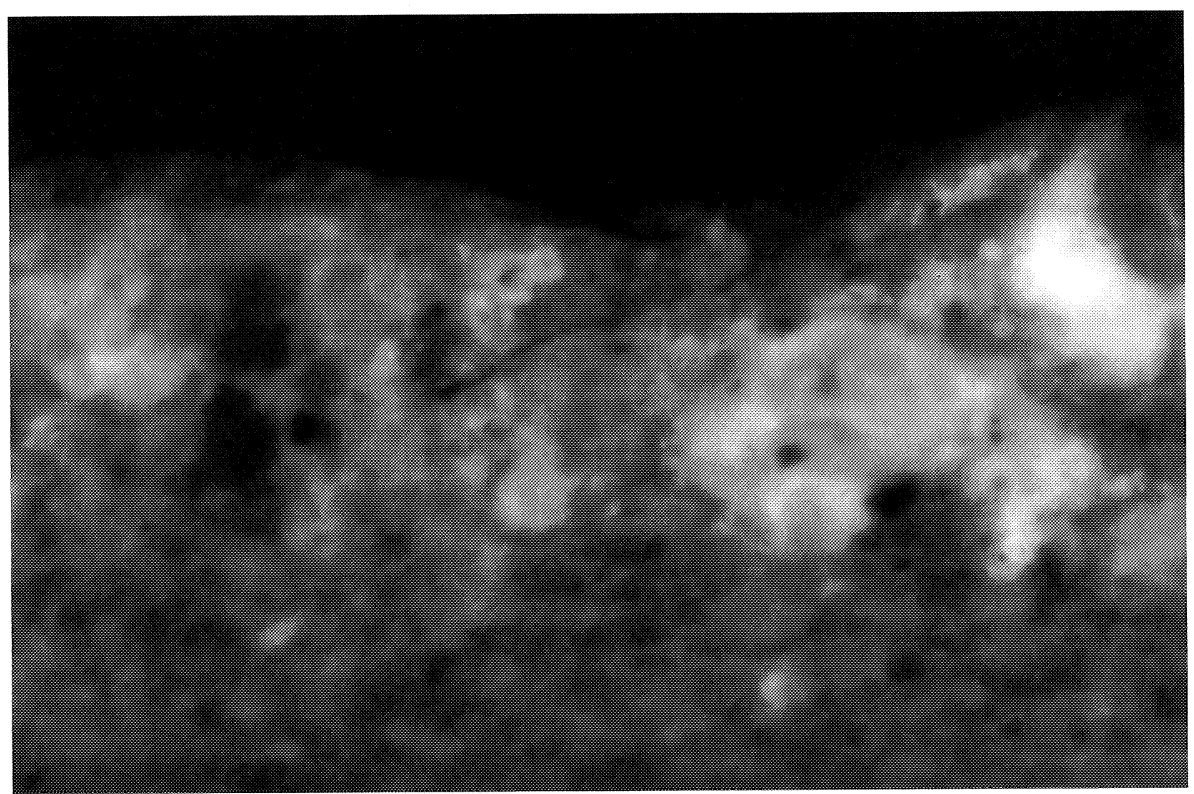


azul y los brocados. Se evitó aplicar la cola caliente, en el primer caso por tratarse de un temple y en el segundo porque ésta podría fundir la mezcla de cera - resina y dañar irreparablemente los relieves. La limpieza fue igualmente muy superficial y tampoco reintegraron las amplias lagunas existentes en las decoraciones aplicadas, por considerar que los vestigios eran muy escasos y que no tenía sentido falsear la historia de la pieza. Unicamente se hicieron calcos de las decoraciones para el estudio estilístico de la escultura y su comparación con otras obras contemporáneas.

Cuando se instala un andamio en obras de grandes dimensiones, como los retablos mayores de El Espinar y Colmenar Viejo, podemos acceder a lugares que se encuentran ocultos normalmente al espectador. Ambos retablos están muy próximos entre sí, se sitúan en pleno Renacimiento, que es la época de mayor florecimiento de la policromía. Están formados por sotabanco, banco, 3 cuerpos y ático y se trata de conjuntos compuestos de esculturas policromadas y tablas pintadas, se suceden en el tiempo y han sido contratados a un mismo taller, pero presentan ciertas diferencias que interesa recalcar.

El retablo de San Eutropio de El Espinar tiene tres calles, dos entrecalles y dos pulseras (figura 6). La talla data de 1565 a 1573 y se ha atribuido tradicionalmente a Francisco Giralte, según consta en el contrato, aunque se aprecia la intervención de otras manos, entre las cuales se encontraría Manuel Manzano. La policromía y la pintura fueron realizadas por Alonso Sánchez Coello y Santos Pedril, de 1574 a 1577. El de Colmenar está dedicado a Nuestra Señora de la Asunción, es de la segunda mitad del siglo XVI y posterior al retablo de El Espinar y tiene 11 calles. La arquitectura y la escultura de la obra fueron talladas por Giralte entre 1560 y 1580 y está documentado que la pintura y la policromía las realizó Alonso Sánchez Coello con su taller.

Antes de decidir el tratamiento a seguir en un retablo hay que poner especial atención en el estado de los elementos constructivos, ya que su estructura suele estar formada por un sencillo armazón de largueros y travesaños de madera y anclajes metálicos recibidos a la pared, que garantizan la estabilidad del conjunto. Se conoce la ordenación de los distintos elementos del retablo de Colmenar: las figuras iban indicadas por medio de letras de izquierda a derecha, los transpilares con números y las cajas y relieves con símbolos.

En el contrato del retablo de El Espinar se establecían una serie de condiciones muy precisas respecto de los materiales y la técnica empleada: Según éste la policromía debía realizarse «in situ», excepto cuatro tablas que pintaría Sánchez Coello en Madrid; el aparejo debía estar 


\section{Marisa Gómez González, Teresa Gómez Espinosa}

6. Fotogrametría del retablo mayor de El Espinar, que sirvió de ayuda para estudiar todos los elementos desde el punto de vista estilístico, iconográfico, analítico y restaurador

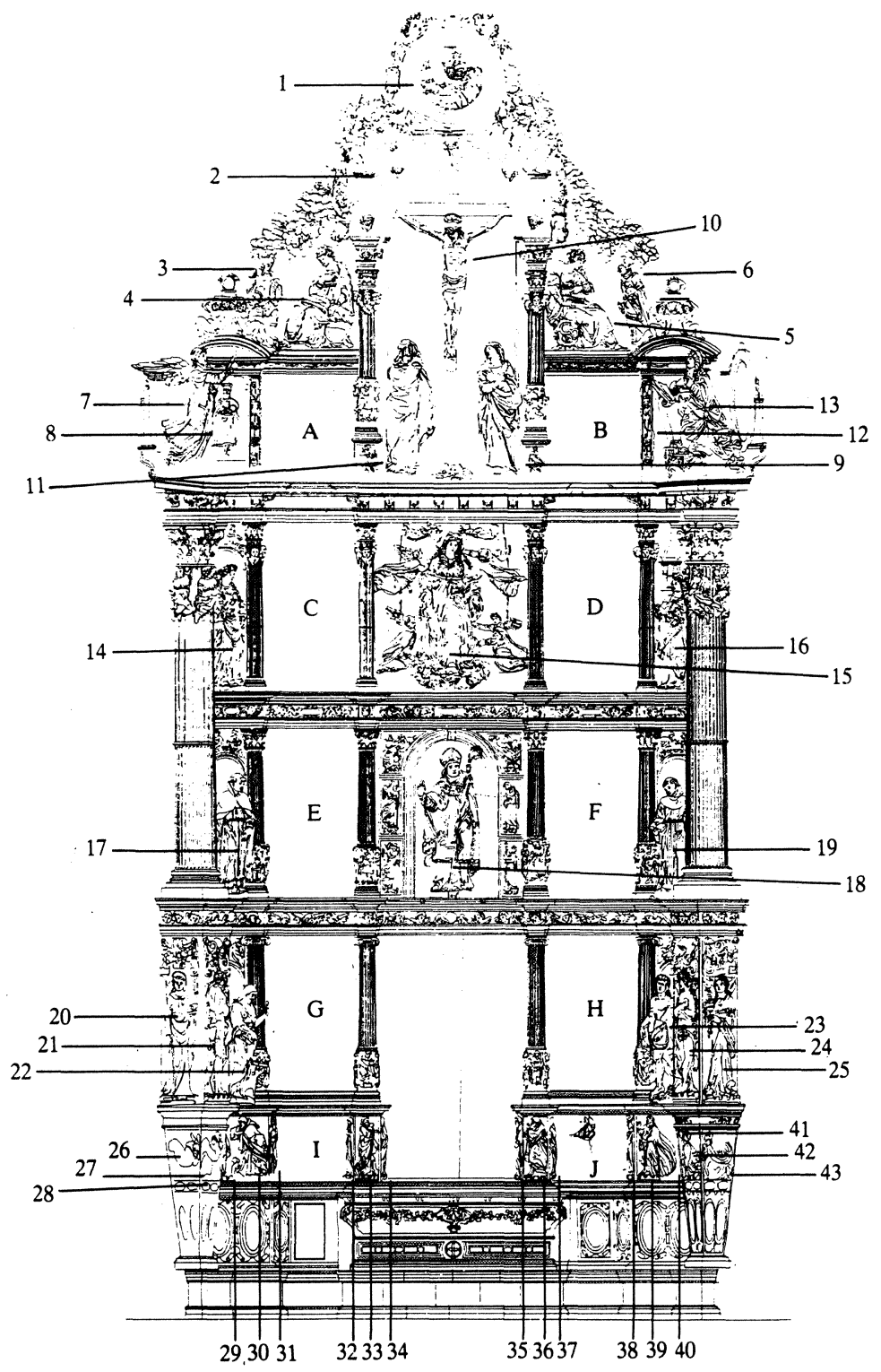


compuesto de yeso y cola animal; se estipulaba el tipo de bol - rojo o de Llanes- y que los dorados fueran de pan de oro bruñido; los pigmentos de los estofados habrían de ser de buena calidad, indicándose la procedencia de los carmines y azules de «muy finas cenizas» asociados a la azurita; la decoración de las columnas debía hacerse al temple y el acabado de grutescos y motivos «a punta de pincel»; las encarnaciones de la escultura tenían que ser pulimentadas y hechas al óleo sobre una imprimación de base; las tablas debían estar pintadas al óleo así como los respaldos del Calvario y la Asunción.

Sánchez Coello cumplió básicamente las condiciones del contrato del retablo del Espinar. Desafortunadamente, del retablo de Colmenar, no tenemos una información semejante que permita comparar las fuentes documentales con los resultados analíticos. La restauración consecutiva de estos dos retablos nos ha permitido, por un lado, contrastar los resultados de los análisis con las condiciones estipuladas en el contrato de El Espinar y, por otro, estudiar las similitudes y diferencias de estas dos obras.

El aparejo, en los dos casos, es de yeso; el bol es una arcilla roja rica en óxido de hierro y el aglutinante es la cola animal: en el retablo de Colmenar Viejo se ha precisado que las capas interiores de aparejo contienen anhidrita, mientras que en las superiores se detecta sólo la forma dihidratada (figura 7, a y b). Los dorados están hechos con pan de oro.

Los azules de El Espinar se componen de azurita aglutinada con clara de huevo. En Colmenar, se reserva este pigmento para construir las capas finales de pintura y los estofados azules de la parte inferior del retablo, siendo sustituido por el índigo en las policromías superiores o por el esmalte en las capas pictóricas más internas.

Los esgrafiados y estofados verdes y los azules de El Espinar presentan granos muy gruesos de azurita y malaquita en cada caso. En Colmenar el uso de estos dos pigmentos es más escaso, y se restringe a las partes inferiores, siendo el molido más fino y las capas mucho más delgadas.

En la mayoría de los estofados de El Espinar el aglutinante parece ser una emulsión óleo/acuosa, mientras que en Colmenar es esencialmente huevo. Las encarnaciones de la escultura, en El Espinar, son emulsiones acuo/oleosas, mientras que en Colmenar han sido realizadas mezclando los pigmentos con aceite de lino, al igual que en las tablas de ambos retablos.

La policromía de los Cristos de los Calvarios se distingue claramente del resto de las esculturas. En El Espinar, varían el espesor de las 
7. (a y b). Espectros de infrarrojos de las capas interiores (a) y más superficiales (b) de la preparación o «aparejo» del retablo de Colmenar. Las primeras contienen anhidrita (a), mientras que las segundas son de yeso (b)

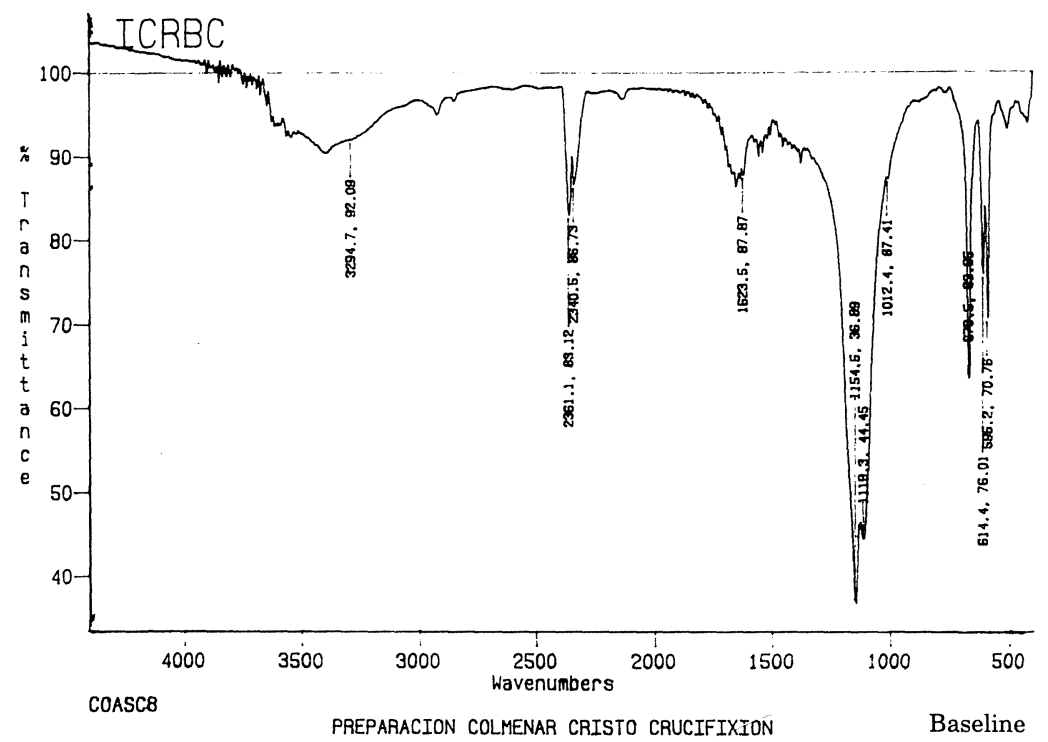

7 (a)

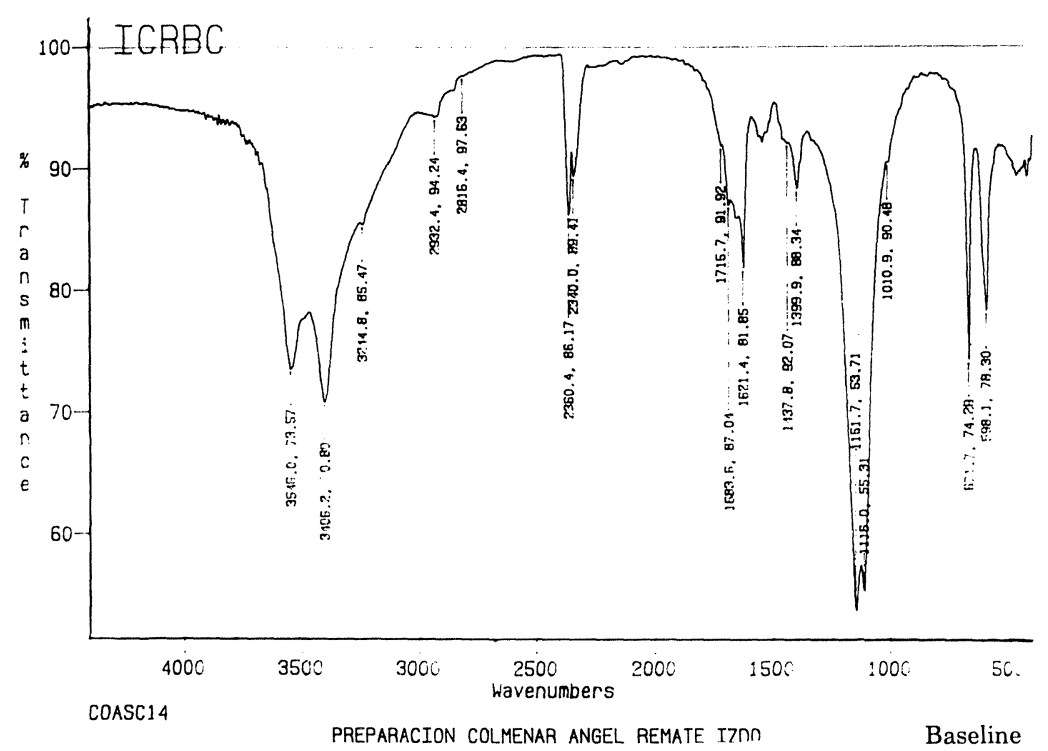

7 (b) 
capas, los pigmentos y el aglutinante: aceite de lino. En Colmenar, la encarnación es mate y de pincelada crispada, a diferencia del resto que están pulimentadas.

De todo ello se deduce que, mientras en El Espinar Sánchez Coello debe atenerse a unas condiciones técnicas fijadas muy estrictamente en el contrato, en Colmenar, años después, aprovecha para hacer un ahorro considerable en los materiales más costosos, como la azurita y la malaquita, en las zonas más altas del retablo y menos visibles, y simplifica la técnica trabajando con más soltura.

El agua procedente de la lluvia y de la nieve se filtraba en el interior de la iglesia de El Espinar, debido al mal estado de la cubierta y lde as ventanas del ábside, afectando al último cuerpo y al ático. También se detectó en este retablo el ataque de insectos xilófagos. Ambos retablos presentaban acumulaciones de polvo y hollín, que ocultaban la delicadeza de las policromías. Las encarnaciones y los cabellos de mujeres y niños de El Espinar habían sido repolicromados posteriormente.

Antes de proceder a la restauración del retablo de El Espinar, se resolvieron los problemas del inmueble que dañaban el conjunto. Se limpió el polvo y el escombro de la zona posterior del retablo, se aplicaron productos insecticidas en las zonas desnudas de la madera y se consolidaron los elementos dañados, pero no se restituyeron los elementos faltantes de volumen. La limpieza exigió numerosas reuniones de la comisión de trabajo que llevaron a determinar el aparente buen estado de la policromía interna a través de calas combinadas con los análisis. Dado que las vestiduras presentaban bellísimas decoraciones renacentistas, se decidió eliminar las partes falseadas por un cambio de gusto y dotar al conjunto de una unidad de la que carecía. Así se resaltaron los cabellos dorados de mujeres y niños y se diferenciaron las encarnaciones de éstos, más claras, de las de los hombres. En cuanto a las lagunas de la policromía, se consideró que la madera y el mismo bol entonaban perfectamente en el conjunto de la obra, al contrario de las que presentaban preparación, que fueron reintegradas por yuxtaposición lineal de colores puros $^{8}$.

En Colmenar se siguieron criterios semejantes dando prioridad a la conservación ante la restauración ${ }^{9}$. En este caso no se levantó el repinte de la predela, que imitaba un marmoleado, por considerar que el original se hallaba en estado ruinoso y, sin embargo, se retiraron algunas figuras incorporadas posteriormente al retablo, dejando las hornacinas vacías, ya que, tanto desde el punto de vista estilístico 


\section{Marisa Gómez González, Teresa Gómez Espinosa}

como iconográfico, se consideró que alteraban la comprensión de la obra, decisión tomada en conjunto por el equipo de trabajo, los historiadores invitados y el párroco. Los problemas constructivos que presentaba se subsanaron sin recurrir al desmontaje.

Por último, exponemos el caso de un retablo gótico inglés del siglo $X I V$, de alabastro policromado y de pequeñas dimensiones, que representa siete escenas de la Vida de la Virgen, expuesto actualmente en el Museo Arqueológico de Madrid.

Como es habitual en los conjuntos de alabastro, la policromía es parcial para aprovechar la nobleza y calidad propias de este material pétreo. El alabastro se ha policromado originalmente de forma parcial. La delicadeza de esta policromía supone una dificultad para su conservación y esto hace más relevante el papel que han desempeñado los estudios previos y los análisis de laboratorio en las distintas fases de la restauración. Muchas de estas obras han sufrido intervenciones muy importantes en el pasado, que han alterado su estética, complicando la interpretación de los resultados.

Cuando el retablo llegó al Instituto formaba un conjunto compuesto por dos cuerpos, ático y tres calles. Gran parte de los fondos de las escenas estaban perdidos y presentaban amplias reconstrucciones de yeso (figuras 8 y 9). El aspecto acromático de la superficie, con tonos grises, pardos y negros, se debía a la suciedad, una fina capa de protección general de cera de abeja, acumulaciones desiguales de barnices y numerosos repintes blancos y negros, que ocultaban la policromía original.

El retablo de la Vida de la Virgen provenía de la iglesia de Santa María la Vieja de Cartagena, aunque su tipología es semejante a los pequeños retablos medievales ingleses y normandos. D. Artioli y sus colaboradores analizaron en 1986 el retablo gótico tardío de la Pasión de Venafro del siglo XV y procedencia inglesa (Nottingham). Hicieron fluorescencia de rayos $\mathrm{X}$, «no destructiva», microscopía óptica y ensayos microquímicos y obtuvieron más datos sobre los materiales que sobre la técnica, tal vez por no poder disponer de muestras suficientes y por la amplitud de los repintes que enmascaraban el aspecto de la policromía original. Los análisis publicados por los laboratorios de investigación de los museos franceses sobre el retablo normando de Rouvray, policromado en el siglo XVI, indican que la policromía es muy semejante a la de la Vida de la Virgen.

Hemos podido comparar los resultados de los análisis de la policromía de los retablos medievales ingleses y normandos mencionados y el de la Vida de la Virgen del Museo Arqueológico, con la investigación de 
Retablo de la Vida de la Virgen. La Anunciación. Esquemas de localización: muestras, alteraciones, adiciones y limpiezas

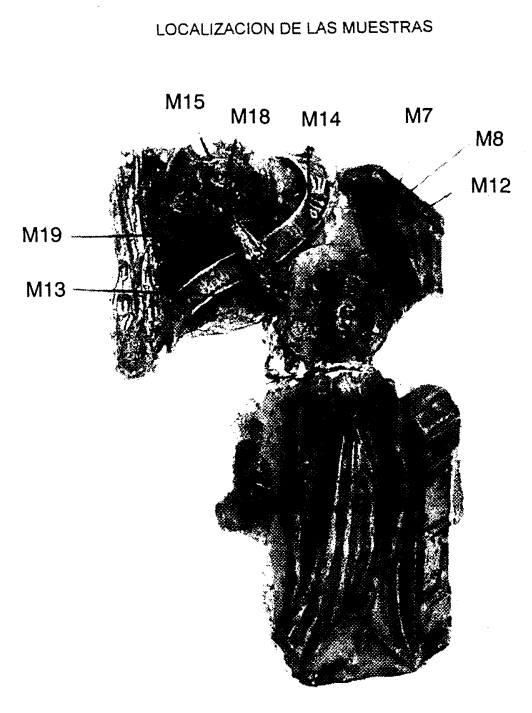

Fig. 8

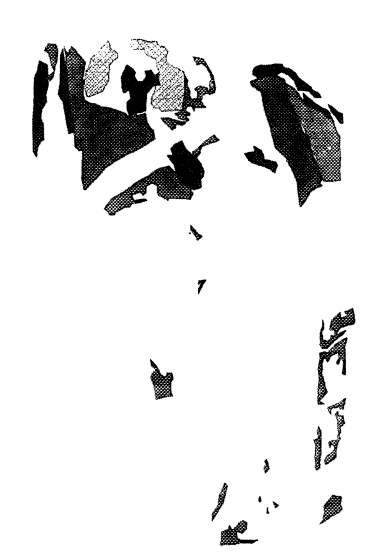

Repinte marrón

Fig. 10
LOCALIZACIÓN Y TIPOLOGIA DE DAÑOS
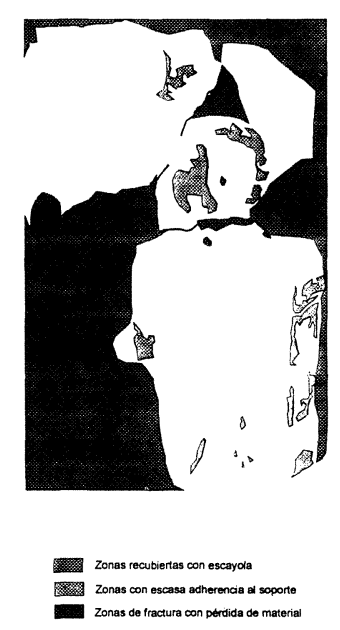

Fig. 9
SISTEMAS DE LIMPIEZA EMPLEADOS PARA LA
ELIMINACIOON DE REPINTES

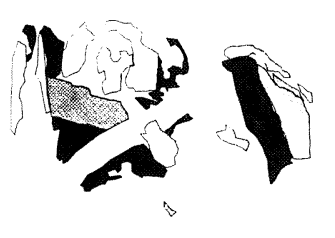

v

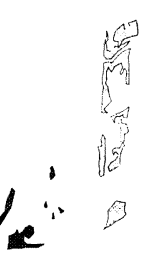

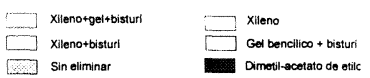

Fig. 11 
los grandes conjuntos retablísticos renacentistas españoles, localizados en Castilla y Aragón -El Pilar y la Seo de Zaragoza, la Catedral de Huesca y El Paular-, ya analizados en el IPHE.

El examen preliminar de la superficie con el microscopio estereoscópico y los análisis de las muestras permitieron reconstruir el aspecto de la policromía primitiva. Todos los fondos superiores del retablo de la Vida de la Virgen estaban originalmente dorados y llevaban decoraciones formando pequeños botones en relieve de tipo pastillaje o barbotina, mientras que las partes inferiores simulaban verdes praderas con flores blancas. Las vestiduras y arquitecturas de las escenas tenían motivos decorativos que se destacaban sobre el fondo de alabastro. Por último, las encarnaciones no llevaban una policromía cubriente, sino una pátina transparente sobre el alabastro y realces puntuales en ojos y labios. El relleno de los relieves de los fondos dorados era de carbonato de calcio y la lámina de oro se apoyaba sobre una doble capa anaranjada espesa y compacta, de minio y tierra roja. Se han identificado también corlas de laca roja. Los tonos opacos blancos, rojos, anaranjados, azules y verdes, se componían respectivamente de albayalde, cinabrio, minio, azurita y una veladura a base de cobre. No se ha podido determinar la composición de la fina pátina que matizaba las encarnaciones no ha logrado determinarse por hallarse enmascarada por una capa de cera aplicada posteriormente sobre toda la superficie.

Los retablos ingleses y normandos tenían, al parecer, un marco de madera, al igual que ciertos conjuntos renacentistas españoles de pequeñas dimensiones, que mantienen sus marcos originales. También el guardapolvo que enmarca los aragoneses de mayor tamaño es de madera, a excepción de El Paular que es de alabastro

El fondo decorado con relieves y dorado totalmente supone un atavismo medieval, más próximo a la estética de la policromía sobre una piedra caliza o una decoración mural. Desaparece en los retablos renacentistas españoles, en los que el alabastro desempeña un papel más importante, y la talla muestra también una mayor variedad de texturas que armonizan con la policromía. Los dorados del retablo de la iglesia de Santa María de Cartagena llevan el mismo tipo de relieves de creta que el de Rouvray y en cambio el mixtión pigmentado es más fino y menos compacto en el retablo normando, aunque se detectan dos capas sucesivas, la inferior anaranjada, como las del Museo Arqueológico de Madrid, y la superior más parda y translúcida. Esta última es semejante a los mixtiones de los alabastros renacentistas españoles. 
Diagnóstico y metodología de restauración........

El alabastro de las encarnaciones de los citados retablos medievales presenta una pátina transparente con realces coloreados puntuales, a diferencia de los retablos renacentistas, cuya policromía es bastante cubriente - de color rosado en las figuras femeninas y más oscuro en las masculinas-, y más acorde con el naturalismo de la época.

La primera etapa de la restauración del retablo de la Vida de la Virgen consistió en desmontar las escenas y retirar la grosera reparación hecha con yeso, resultando que muchas de ellas estaban fragmentadas. La limpieza exigió el empleo de diferentes productos dependiendo del tipo de material (figuras 10 y 11). Después de múltiples ensayos con el microscopio estereoscópico, renunciamos a levantar todos los repintes que podían hacer peligrar la delicada policromía original, ya en sí bastante perdida. No se restituyeron de nuevo las áreas faltantes del soporte ni de la policromía, aunque se rellenaron las grietas y se entonaron por medio de veladuras. Para finalizar, se protegieron únicamente las zonas policromadas con una fina capa de barniz natural al que se había añadido un estabilizante ${ }^{10}$. El Museo Arqueológico se encargó de montar las escenas en una sola calle apoyada sobre un soporte de madera.

En este apartado no hemos tratado de agotar todas las cuestiones relacionadas con la restauración de esculturas policromadas, ya que la variedad de soportes y técnicas de la policromía es el único aspecto a tener en cuenta. Ya hemos visto que la historia material de la obra, el entorno y las incidencias que éste haya sufrido y un sinnúmero de factores también intervienen. De cualquier forma, es evidente que el tratamiento de una imagen de culto tiene unos condicionantes distintos a los de las tallas expuestas en un museo o los retablos de grandes dimensiones, cuyos detalles se pierden en el conjunto monumental. En el primer caso, se crea una comisión de seguimiento en la que se incluye a representantes del clero y las cofradías y en los últimos hay que contar con delegados de la administración. En las obras contempladas en los museos se pueden seguir criterios técnicos más puristas y se pueden realizar tratamientos mínimos, porque las condiciones ambientales van a estar más controladas. Los grandes retablos imponen evaluar el coste del trabajo y los plazos, así como valorar los resultados en función de un conjunto.

\section{Agradecimientos}

A la dirección del Instituto del Patrimonio Histórico Español, por permitirnos presentar la documentación ilustrativa del artículo; a Ara- 
celi Gabaldón y Tomás Antelo, que han realizado la radiografía de San Jerónimo; a Ana Carrassón y a Concha Cirujano, restauradoras de escultura policromada en madera y piedra y a Rocio Bruquetas restauradora de pintura, que nos han ofrecido una parte de la información documental y gráfica elaborada por ellas.

\section{Notas}

1 Definición adoptada por el Grupo Latino de Escultura Policromada.

2 Estos dos últimos grupos apenas los mencionaremos en este estudio de carácter general, ya que su interés se restringe a determinados períodos de la historia o bien a modelos y figuras de pequeño formato.

3 Atenas (1931), Nueva Delhi (1956), Venecia (1964), París (1972), Amsterdam (1975), Florencia (1981), Roma (1987).

4 El yeso es sustituido por el carbonato de calcio o la dolomita en las policromías de los Países Bajos, Alemania y el Norte de Francia.

5 Arcilla homogénea y compacta que puede alisarse con bruñidor de ágata.

6 La imagen fue restaurada por Marta Fernández de Córdoba.

7 Trabajo realizado por Félix Yamandu, bajo la dirección de Antonio del Rey.

8 La restauración fue coordinada por Rocio Bruquetas, Carmen Levenfeld, Pilar y Ubaldo Sedano.

9 Las coordinadoras fueron esta vez Ana Carrassón y Rocío Bruquetas.

$10 \mathrm{El}$ retablo ha sido restaurado por Concha Cirujano.

\section{Bibliografía}

Ballestrem, A., «Sculpture polychrome. Bibliografie», Studies in Conservation, 15, Londres, 1970, 253-271.

Bruquetas R., Carrassón A., «Retablo de Nuestra Señora de la Asunción de Colmenar Viejo, proceso de ejecución", Actas Congreso Nacional Madrid en el Contexto de lo Hispánico desde la época de los Descubrimientos, t. II, Madrid, 1994, pp. 1303-1315. "La restauración de los retablos monumentales. Tres ejemplos", La conservación del Patrimonio en el mundo mediterráneo. I Encuentro, "Criterios de intervención», Peñíscola, 1994, pp. 119-125.

CABRERA, J.M., RECCHUTO, A., "Study of the materials and technique of the polychromed sculpture. Virgen de la Oliva (by Alonso Cano. Spanish XVII century)", The International Council of Museums. Committee for Conservation, Madrid, 1972.

Cennini, C., El libro del arte (1437), Barcelona, 1979, Ed. Cátedra, Madrid, 1990.

Dielafoy, M., L'estatuaire polychrome en Espagne, París, 1908.

Doerner, M., Los materiales de la pintura y su empleo en el arte, Barcelona, 1989.

Echevarría GoÑi, P., Escultura del Renacimiento en Navarra, Pamplona, 1990, Policromía renacentista y barroca, Cuadernos de Arte Español, n 48, Madrid, 1992. 


\section{Diagnóstico y metodología de restauración.......}

García Chico, E., Documentos para el estudio del Arte en Castilla, vol. II, Escultores, Valladolid, 1941. Vol. III, Pintores, Valladolid, 1946.

García RAmos, R., «Examen material de la obra de arte. La correspondencia de policromías», Boletín Informativo del Instituto Andaluz de Patrimonio Histórico, $\mathrm{n}^{\circ}$ 12 , 1995, 52-57.

Garcfa Ramos, R., Rutz de Arcaute, E., "Aproximación al brocado aplicado en España. Desarrollo y extensión", Actas Congreso Nacional de Restauración Castellón, 1996, pp. 747-746.

Gómez Espinosa, T., y otros, "The Conservation and Restoration of a processional imagen: the Christ of the Expiration", Actas Congreso IIC, Madrid, 1992, 57-61. Nuestra Señora de África. Proceso de restauración, Madrid, 1992.

Gómez Espinosa, T., «Contribución de la Ciencia al estudio técnico de la escultura en madera policromada", Actas Congreso Nacional Madrid en el Contexto de lo Hispánico desde la época de los Descubrimientos, t. II, Madrid, 1994, pp. 1341-1355. «La policromía del Gótico final. El retablo mayor de la catedral de Toledo y obras burgalesas de Gil Siloe», Congreso Internacional Gil Siloe y su época, Burgos, 1999 (en prensa).

Gómez GonzÁlez, M. L., La Restauración, Examen científico aplicado a la conservación de obras de arte, Cátedra Cuadernos Arte, Instituto del Patrimonio Histórico Español, Madrid, 1998, $2^{\text {a }}$ Ed. 2000. «Evolución técnica y variaciones de los materiales de dos retablos del mismo autor: Colmenar Viejo y El Espinar" Actas Congreso Nacional Madrid en el Contexto de lo Hispánico desde la época de los Descubrimientos, t.II, 1994, pp. 1357-1368. «Examen científico del Santo Entierro de Granada, atribuido a Jacopo Torni", X Congreso de Conservación de Bienes Culturales, Cuenca, 1994, pp. 263-272.

GómEz M. y otros, "Albâtre polichrome des XV et XV $\mathrm{X}^{\mathrm{e}}$ siècles en Espagne. Caracterisation des materiaux", Actas congreso Art et Chimie, la couleur, CNRS Ed, París, 2000, pp. 80-87.

Gómez MoReno, M.E., La policromía en la escultura española, Madrid, 1943.

Hasbach Lugo, B., Escultura policromada del siglo XVI en España. El Entierro de Cristo de Juan de Juni en Valladolid, México, 1980. «Technique and restoration of three sculptures by Pedro de Mena", Actas Congreso IIC, Madrid, 1992.

Herranz Garcia, E., El arte de dorar, Madrid, 1975.

López Martinez, C., Retablos y esculturas de traza sevillana, Sevilla, 1928.

MARTIN GoNZÁlEZ, J.J., "La policromía en la escultura castellana», AEA, vol. XXVI, 1953, 295-312. Escultura barroca castellana, Madrid, 1959. Escultura barroca en España, 1600/1700, Madrid, 1983, El retablo Barroco en España, Madrid, 1993.

Martin González, J.J., Cruz Solís, J., El entierro de Juan de Juni. Historia y Restauración, Valladolid, 1983.

Masschelein-KLeiner, L., Liants, vernis et adhésifs anciens, Cours de Conservation 1, Bruselas, 1983.

Mattein, M., Moles, A., La chimica nel restauro. I materiali dell'arte pittorica, Ed. Nardini, Florencia, 1989. Scienza el restauro. Metodo de indagine, Ed. Nardini, Florencia, 1984.

MaYer, R. Materiales y técnicas del arte, Ed. Hermann Blume. Madrid, 1993.

Monen J.P., L'Art et la Science, l'esprit des chefs- d'oeuvre, Decouvertes Gallimard, París 1996. 


\section{Marisa Gómez González, Teresa Gómez Espinosa}

Navarro, V., Técnica de la escultura, Barcelona, 1976.

PACHeCo, F., El arte de la pintura (Sevilla, 1649), Madrid, 1956 (edic. preparada por F. Sánchez Cantón), Ed. Cátedra, 1990.

Palomero Páramo, J.M., El retablo sevillano en el renacimiento: Análisis y evolución (1560-1629), Sevilla, 1983.

Palomino, A.A., El Museo pictórico y Escala óptica (Madrid, 1715), Buenos Aires, 1944, Ed. Aguilar, Madrid, 1988.

Pantorba, B., Imagineros españoles, Madrid, 1952.

Quinto De Romero, M.L., Los batihojas, artesanos del oro, Madrid, 1984.

RECCHUTO Genovese, A., "Metodología para el estudio, conservación y restauración de la policromía de la escultura española en madera", Boletín del ICCR, 1970, 45-50. "La Virgen de las Angustias de Juan de Juni. Estudio para su conservación y restauración", Bol. del ICCR, 1972, pp. 5-16.

SÁnchez Mesa Martín, D., "La policromía en las esculturas de Cano", Estudios del III centenario de Alonso Cano en Granada, Granada, 1969, 231-243. Técnicas de la escultura policromada granadina, Granada, 1971.

Serck Dewaiden, M., «Application de la radiographie á l'examen des sculptures polychromes». Bulletin Institute Royal du Patrimoine Artistique, XVII, Bruselas, 1978-79, 231 y ss.

VANDER VOORDE, G., «Het volledig radiograferen van voluminenze driedimensionale Kunstuoorwerpe», Bulletin Institute Royal du Patrimoine Artistique, XVII, Bruselas, 1978-79, 22-39.

VARIos, Ciencia pensamiento y Cultura. Conservación del Patrimonio Artístico, Arbor, P. Sedano Ed., Madrid, 1999.

VArios, Santísimo Cristo de la Fundación. Proceso de restauración, Sevilla, 1989.

VARIOS, El retablo y la sarga de San Eutropio del Espinar, ICRBC, Dirección General de Bellas Artes, Ministerio de Cultura, Madrid, 1991.

VARIOS, Retablo renacentista de Bidaurreta. Restauración, Ondare, Diputación Foral de Guipuzcoa, 1991.

VARIos, Renacimiento y Humanismo en Navarra. El retablo de Genevilla, Panorama, 19, Pamplona, 1991.

VARIOS, La vie mystérieuse des chefs-d'oeuvre. La science au service de l'art, Ed. de la Réunion des musées nationaux, París, 1980.

VARIOS, Metodo e scienza. Operativita e ricerca nel restauro, Ed. Sansoni, Florencia, 1982.

VARIOS. Artists Pigments. A handbook of their History and characteristics, Ed. R.L. Feller, National Gallery of Art and Cambridge University Press, 1986.

VARIOS, Artists Pigments: A handbook of their history and characteristics, Vol.2. Ashok Roy Ed., Washington, 1993.

VARIOS, Artists Pigments: A handbook of their history and characteristics, Vol.3. Elisabeth West Fitzhugh Ed., Nueva York, Oxford, 1997.

Witrkower, R., La escultura: procesos y principios (1977), Madrid, 1988. 